\title{
Role of dual source multidetector row cardiac computed tomography angiography in diagnosis and management of congenital heart disease patients
}

\author{
Narumol Chaosuwannakit \\ Department of Radiology, Khon Kaen University, Khon Kaen, Thailand
}

Kardiochirurgia i Torakochirurgia Polska 2017; 14 (3): 180-185

\begin{abstract}
Introduction: Primary evaluation of patients with congenital heart disease (CHD) traditionally relies on echocardiography and conventional cardiac angiography (CCA), both of which have potential limitations.

Aim: To test the hypothesis that cardiac computed tomography angiography (CCTA) is useful in the diagnosis and management of these patients.

Material and methods: The 3-year observational, analytical, retrospective, cohort study included a total of 111 tomographic studies of patients with congenital heart disease. Computed tomography scans were read twice and medical records were reviewed. The Aristotle complexity was assessed as well as and the contribution of new data in relation to clinical suspicion and diagnostic change was evaluated by two expert readers who were blinded for clinical outcome in consensus reading. The confidence interval was set at $95 \%$ and a $p$-value of $<0.05$ was used as the cutoff for statistical significance.

Results: In total, 111 patients were included (56 men and 55 women) with a mean age of 7.2 years ( 1 day- 71 years). The therapeutic procedure was performed without additional tests in $85.8 \%$ of patients. New findings were observed in $60.4 \%$ of patients and a subsequent change in management in $46.9 \%$. New unexpected findings in CCTA prompted changes in management in $86.8 \%$ of patients. There were no significant differences in age between patients with new findings vs. patients without such findings in CCTA suggesting that CCTA-supported diagnosis of CHD is independent of age.

Conclusions: Use of dual-source cardiac computed tomography yields good diagnostic performance in congenital heart disease, prompts changes in management in more than onethird of patients, and reveals new findings in relation to the presumed diagnosis in most patients.

Key words: congenital heart disease, cardiac computed tomography angiography, multidetector row computed tomography.
\end{abstract}

\section{Streszczenie}

Wstęp: Pierwotna ocena pacjentów z wrodzonymi wadami serca tradycyjnie opiera się na echokardiografii i konwencjonalnej angiografii, przy czym obie te metody wiążą się z pewnymi ograniczeniami.

Cel: Sprawdzenie użyteczności angiografii tomografii komputerowej w diagnostyce i postępowaniu u tych pacjentów.

Materiał i metody: Trzyletnie obserwacyjne, analityczne, retrospektywne badanie kohortowe objęło łącznie 111 badań tomograficznych pacjentów z wrodzonymi wadami serca. Obrazy tomografii komputerowej odczytano dwukrotnie i dokonano przeglądu dokumentacji medycznej. Stopień złożoności planowego zabiegu według systemu Aristotle oraz wpływ nowych danych w odniesieniu do podejrzeń klinicznych i zmiany rozpoznania oceniało dwóch specjalistów nieznających wyniku klinicznego. Przedział ufności ustalono na 95\%, a jako graniczną wartość istotności statystycznej przyjęto $p<0,5$.

Wyniki: W badaniu wzięło udział łącznie 111 pacjentów (56 płci męskiej i 55 płci żeńskiej) w wieku średnio 7,2 roku (od 1 dnia do 71 lat). Zabieg leczniczy wykonano bez dodatkowych badań u 85,8\% pacjentów. Nowe nieoczekiwane wyniki angiografii tomografii komputerowej uzyskano u 60,4\% pacjentów i spowodowały one zmianę strategii leczenia u 46,9\% pacjentów. Spośród chorych z nowymi danymi u 86,8\% nastąpiła zmiana postępowania. Ponadto nie stwierdzono istotnych różnic wieku między grupą chorych z nowymi danymi a grupą bez nieoczekiwanych znalezisk w tomografii komputerowej, co sugeruje, że rozpoznanie wrodzonych wad serca z zastosowaniem tomografii nie zależy od wieku.

Wnioski: Zastosowanie dwuźródłowej tomografii komputerowej serca jest skuteczną metodą diagnostyczną w przypadku wrodzonych wad serca. Powoduje zmianę postępowania u ponad 1/3 pacjentów i ujawnia nowe fakty w stosunku do zakładanego rozpoznania u większości pacjentów.

Słowa kluczowe: wrodzone wady serca, angiografia tomografii komputerowej serca, wielorzędowa tomografia komputerowa.

Address for correspondence: Assoc. Prof. Narumol Chaosuwannakit PhD, Department of Radiology, Khon Kaen University, 499/132 Mittraparb Road, Muang District, 40000 Khon Kaen, Thailand, phone: 66846464640, e-mail: narumol_chao@yahoo.com

Received: 15.08.2017, accepted: 6.09.2017. 


\section{Introduction}

Congenital heart disease (CHD) is defined as any structural heart defect with potential clinical significance. Its incidence ranges between 4/1000 live births and 12/1000 live births and the most common CHDs are major congenital defects. The majority of CHDs are due to abnormalities that develop between 3 and 10 weeks of gestation and are dynamic entities that have a different course in each patient. There is a progressive decrease in mortality because of improvement of diagnosis and treatment and thus an increase in survival (approximately $85-90 \%$ of CHD patients reach adulthood) [1]. Although it is difficult to determine the influence of imaging techniques on the increase in survival, there has been a demonstrated increase in the detection of CHD following the introduction of multidetector computed tomography (MDCT). The diagnostic information obtained using low-risk techniques is essential for optimal medical and surgical management [2-4] and perioperative imaging is useful in assessing procedural success $[5,6]$. Continuing advances in medical imaging have made it possible to diagnose cardiovascular disease in any patient by the use of different methods involving a wide variety of technical requirements, benefits, limitations, and costs. The correct application of each method requires a well-integrated group of experts who collaborate with the clinical diagnostic services $[7,8]$. There is a trend toward the decreased use of diagnostic catheterization despite it being the reference diagnostic technique, and its use is now mainly reserved for therapeutic decision-making [9]. The incorporation of cardiac computed tomography angiography (CCTA) led us to reflect on the capacity of this new technique to provide answers to the clinical problems of CHD patients and evaluate its implications for their subsequent management. This article assesses the impact of the introduction of CCTA on the management of CHD patients.

\begin{abstract}
Aim
As far as we know, this is the first study to analyze the clinical application of CCTA in Thailand of mainly pediatric CHD patients, in relation to the reports submitted to clinicians, and to determine the role, accuracy, and safety of this technique for this group of patients.
\end{abstract}

\section{Material and methods \\ Patient population}

This retrospective study included 111 patients with diagnosis of congenital heart disease by clinical data and initial echocardiography who underwent CCTA between February 2013 and December 2016. The indication for CCTA was pre- or postoperative evaluation of congenital heart disease patients, which is considered an appropriate indication for CCTA, based on the criteria of the American College of Cardiology (ACC) [10]. Exclusion criteria for CCTA included the presence of renal failure and a history of allergic reaction to iodine-containing contrast agents. The present study was approved by the Ethics Committee of the Faculty of Medicine and informed consent was obtained from all patients.

\section{Dual-source MDCT scanning protocol}

Short-term IV sedation is often required, particularly in children under 5 years of age, and the imaging can be performed during quiet breathing. Imaging was performed by using a dual-source MDCT scanner (Somatom Definition; Siemens Healthcare, Forchheim, Germany). The radiation dose is kept to a minimum by reducing the kilovoltage and tube current appropriately. For children weighing less than $10 \mathrm{~kg}, 10-19 \mathrm{~kg}$ and $20-30 \mathrm{~kg}$, we use $80 \mathrm{kV}$ and $80 \mathrm{mAs}$, $80 \mathrm{kV}$ and $100 \mathrm{mAs}$, and $100 \mathrm{kV}$ and $120 \mathrm{mAs}$, respectively. Other cardiac CT angiographic parameters were as follows: number of X-ray tubes, two; collimation, 128 detector rows of $0.5 \mathrm{~mm}$ each, with double sampling by using rapid alteration of the focal spot in the longitudinal direction ( $z$ flying focal spot) [11], rotation time ms, 330; tube voltage, $100 \mathrm{kV}$; and full tube current. Prior to scanning, the pitch was set automatically by the scanner software. Depending on heart rate, pitch was set between 0.2 and 0.43 . Automated dose regulation methods such as CARE dose 4D (Siemens Healthcare) may be used to reduce the radiation. Image acquisition was performed during inspiratory breath-hold for older children or adult. To familiarize the patient with the protocol, breath-holding was practiced before the examination. A bolus of iodinated contrast material (350 mg/ $\mathrm{ml}$, Omnipaque; GE Healthcare) at a dose of $1.5 \mathrm{ml} / \mathrm{kg}$ with a dual-head power injector at a rate of $1.5-2.0 \mathrm{ml} / \mathrm{s}$ for a 22-gauge cannula, $3.0 \mathrm{ml} / \mathrm{s}$ for a 20-gauge cannula and 4.0-5.0 ml/s for a 18-gauge cannula followed by $10-20 \mathrm{ml}$ of saline flush at the same rate as that of the contrast injection was applied. For timing purposes, automated bolustracking software was used, starting the scan automatically $6 \mathrm{~s}$ after contrast agent density in the descending aorta reached a predefined threshold of $130 \mathrm{HU}$ [12]. The entire volume of the heart and pulmonary arteries was covered during one breath-hold in approximately $5 \mathrm{~s}$ with simultaneous recording of the ECG trace. Patients were scanned in the supine position. The CCTA is performed from the thoracic inlet level to the diaphragm. When there is suspicion of anomalous pulmonary venous drainage, the scan can be extended down to the lower border of the liver.

\section{Cardiac computed tomography angiography image analysis}

Cardiac computed tomography angiography image analysis was performed by two cardiovascular and thoracic radiologists in consensus (with respectively 11 and 10 years of experience in examining cardiovascular and thoracic CT scans) and blinded to the clinical data and the results of CCA data. First, all axial image data are evaluated using a 3D post processing workstation with Syngo software (Siemens Healthcare). Various image reformatting techniques including curved planar reconstruction, maximum intensity projection (MIP), minimum intensity projection, and volume-rendering technique (VRT) are used to obtain 
Tab. I. Most common specific diagnoses in cardiac computed tomography angiography

\begin{tabular}{lc} 
Variable & $\begin{array}{c}\text { Number } \\
\text { of patients }\end{array}$ \\
\hline Pulmonary atresia with ventricular septal defect & 32 \\
\hline Tetralogy of Fallot & 5 \\
\hline Transposition of great arteries & 12 \\
\hline Anomalous pulmonary venous return & 10 \\
\hline Coarctation of aorta & 4 \\
\hline Interrupted aortic arch & 2 \\
\hline Anomalous coronary artery & 16 \\
\hline Double outlet right ventricle & 5 \\
\hline Truncus arteriosus & 3 \\
\hline Post bidirectional Glenn shunt & 8 \\
\hline Tricuspid atresia & 2 \\
\hline Post-arterial switch operation & 2 \\
\hline Post-Fontan operation & 10 \\
\hline
\end{tabular}

Tab. II. Change in therapeutic approach

\begin{tabular}{|c|c|c|}
\hline Result & Patients, $n$ (\%) & Total (\%) \\
\hline \multicolumn{3}{|c|}{ No change in management: } \\
\hline Known findings & $22(19.8)$ & \multirow{2}{*}{53.1} \\
\hline New findings & $37(33.3)$ & \\
\hline \multicolumn{3}{|c|}{ Change in management: } \\
\hline New findings & $30(27.1)$ & \multirow{2}{*}{46.9} \\
\hline New diagnosis & $22(19.8)$ & \\
\hline
\end{tabular}

all the clinically relevant information. Curved multi-planar reformatting and MIP are primarily used to evaluate curved structures such as the pulmonary arteries and major aortopulmonary collateral arteries (MAPCAs). Minimum intensity projection is used to evaluate the airway and lung parenchyma. For 3D reformatting of the complex anatomy, VRT is used. Thin-section multiplanar reformatting is used for quantitative analysis of the structure in question.

\section{Data collected}

Population data: age, sex, date of test. Clinical information contained in the test order: purpose and justification of the test and pre- or post-treatment study.

Clinical history: additional pre- and post-CCTA. The complexity of heart disease $[13,14]$ and of each patient was calculated (Aristotle score) [15, 16]. Anatomical findings were coded by group: aortic disease, pulmonary tree, heart disease, anomalous pulmonary venous drainage, complex CHD, post-procedural complications, pulmonary hypertension, airways, and unexpected findings. We assessed whether the findings prompted a change in clinical management, treatment, or patient lifestyle (scored as 1, known findings; 2, new findings without change in management; 3 , new findings with a change in management; 4 , change in diagnosis). We also assessed concordance between the presumptive diagnosis and the diagnostic test: existence of ex- pected or unexpected findings. New findings were defined as any anatomical abnormality not found in previous tests.

A change in diagnosis: changes in CHD complexity, chamber sequence, or in previously diagnosed intracardiac or great vessel defects.

Changes in treatment: from surgery to catheterization, from catheterization to surgery, or changes in the catheterization or surgical technique used.

- No changes in treatment.

- No changes in diagnosis.

Unexpected findings were defined as findings that were not predicted by the known natural history of the main anatomical abnormality or changes in its natural history.

\section{Statistical analysis}

Continuous data were expressed as mean \pm SD. Statistical analyses were performed using SPSS software version 16 (SPSS, Inc., Chicago, IL, USA). A level of $p<0.05$ was considered statistically significant and all reported $p$-values were two-sided. Means were compared using the unpaired $t$-test, and the Mann-Whitney rank sum test was used when data were not normally distributed. Qualitative variables were compared using the Pearson $\chi^{2}$ test or Fisher exact test.

\section{Results}

In total, 111 patients were included (56 men and 55 women) with a mean age of 7.2 years (1 day-71 years). In total, $89.1 \%$ of patients did not undergo further studies. The specific diagnoses in cardiac computed tomography angiography are lists as Table I. The therapeutic procedure was performed without additional tests in $85.8 \%$ of patients. Additional catheterization was performed in $10.8 \%$ of patients. Of the patients studied, $90 \%$ had moderate to severe CHD and $80.2 \%$ had a level of complexity $=9.1$ (level III) according to the Aristotle score. New findings were observed in $60.4 \%$ of patients. Mutually exclusive dichotomous categories were as follows: no change in management (53.1\%), subsequent change in management (46.9\%), of which $19.8 \%$ were due to changes in diagnosis (Tab. II; Figs. 1 and 2). Regarding disease, $44.8 \%$ of new findings were complex CHD, with changes in treatment in $17.9 \%(p<0.001)$, and changes in diagnosis in complex CHD (14.9\%), aortic disease (7.5\%) and coronary artery disease (5.9\%) (Tab. III). Regarding CHD complexity, there were new findings in $81.8 \%$ of patients with severe CHD, with changes in management in $31.2 \%$. There were changes in diagnosis in patients with moderate CHD (18.9\%; $p<0.05)$ and changes in diagnosis in patients with greater complexity (mean score: $3.25 ; p<0.05$ ). All unexpected reports $(100 \%)$ described new findings prompting changes in management in $86.8 \%$ of patients and a new diagnosis in $47.2 \%(p<0.001)$. Patient progression after cardiac computed tomography angiography in shown in Table IV.

\section{Discussion}

The present study demonstrated that cardiac computed tomography angiography (CCTA) is an excellent diagnostic 



Fig. 1. Cardiac computed tomography angiography (CCTA) of a 7-year-old boy with presumed diagnosis of tetralogy of Fallot. The CCTA showing new unexpected findings as pulmonary atresia with ventricular septal defect (PA-VSD), right-sided aortic arch (A; black arrow) and left-sided patent ductus arteriosus (A and B; white arrow) supplying pulmonary arteries causing a change in diagnosis which changed the therapeutic management from total corrected TOF to staged repair of pulmonary atresia with VSD

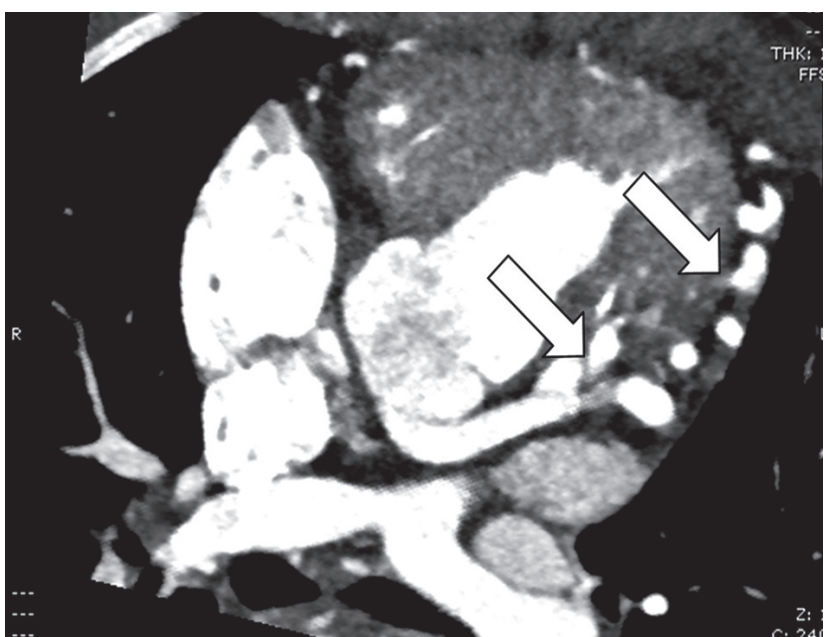

Fig. 2. Cardiac computed tomography angiography (CCTA) of a 5 -year-old girl with presumed diagnosis of pulmonary atresia with VSD. The CCTA showing new unexpected findings as single coronary artery and coronary artery fistula from left anterior descending artery to right ventricle (arrows), which changed the therapeutic management

tool for the comprehensive assessment of patients with congenital heart disease using dual-source MDCT. These results are in line with previous published data on the performance of the older generation CT scanner [17-19]. Regarding all unexpected findings, there was a change in management in $46.9 \%$ of patients. In an MRI study, Secchi et al. [20] found that unexpected reports were associated with more clinically important categories and $85 \%$ of unexpected reports
Tab. III. New findings by disease

\begin{tabular}{|c|c|c|c|}
\hline Disease & $\begin{array}{l}\text { New findings } \\
\text { without change } \\
\text { in management }\end{array}$ & $\begin{array}{l}\text { New findings } \\
\text { with change } \\
\text { in management }\end{array}$ & $\begin{array}{c}\text { Change } \\
\text { in diagnosis }\end{array}$ \\
\hline $\mathrm{CCHD}$ & 18 & 12 & 10 \\
\hline APVC & 2 & 8 & 2 \\
\hline $\begin{array}{l}\text { Pulmonary } \\
\text { artery disease }\end{array}$ & 8 & 5 & 1 \\
\hline Aortic disease & 1 & 3 & 5 \\
\hline $\begin{array}{l}\text { Coronary } \\
\text { disease }\end{array}$ & 8 & 2 & 4 \\
\hline Total & 37 & 30 & 22 \\
\hline
\end{tabular}

CCHD - complex congenital heart disease, APVC - anomalous pulmonary venous connection. Data are expressed as number of patients.

Tab. IV. Patient progress after cardiac computed tomography angiography

\begin{tabular}{lc} 
Variable & Number of patients (\%) \\
Discharge & $4(3.6)$ \\
\hline Medical therapy & $46(41.4)$ \\
\hline Diagnostic catheterization & $12(10.8)$ \\
\hline Therapeutic catheterization & $18(16.2)$ \\
\hline Surgery & $31(28)$ \\
\hline
\end{tabular}

prompted a change in treatment, lifestyle, or diagnosis. No significant differences were found between study periods, indicating that clinicians used consistent criteria when interpreting the test reports. Tsai-Goodman et al. [3] found that $70.3 \%$ of patients who underwent MRI did not require addi- 
tional catheterization. In the present study, $89.2 \%$ of patients did not require additional diagnostic studies. Therefore, the values obtained are better and provide sufficient information for decision making. The technique used is non-invasive and avoids additional risks. Eichhorn et al. [21] also found that multidetector CT has high diagnostic accuracy, avoiding the need for additional techniques to plan the surgical approach. According to these authors, the diagnostic accuracy of CT is comparable to catheterization and is more accurate in detecting other complications that could put the patient at risk. Lee et al. [22] found that additional diagnostic cardiac catheterization was not needed in a group of neonates following 64-MDCT. Vastel-Amzallag et al. [23] also suggested in their study on tetralogy of Fallot that 64-MDCT avoids additional angiographic analysis before corrective surgery. These changes in diagnostic approach have also been addressed in recent publications and guidelines on interventional cardiology [24]. The present study assessed the correlation between the presumptive and definitive diagnosis according to the percentage of unexpected results and diagnostic changes. Unexpected reports described new findings in 100\% of patients and prompted changes in management in $86.8 \%$ of patients. Of these, $47.2 \%$ were new diagnoses. There was a change in management in only $19.5 \%$ of the patients with an expected report. There were no significant differences by age group or expected/unexpected report, suggesting that a diagnosis of CHD is independent of age. Greater complexity was found in patients with unexpected reports and in younger patients in each age group. The clinical value of CCTA can be appreciated by considering what would have happened to patients with unexpected findings. In patients with CHD, CCTA has several advantages compared to MRI, such as the simultaneous assessment of cardiovascular abnormalities via airways, lung parenchyma, and chest wall, short anesthesia times, greater spatial resolution, wider availability and less sensitivity to metal artifacts, and can be performed in patients with pacemakers or claustrophobia $[25,26]$. Although the damage caused by ionizing radiation can lead to cancer and is directly associated with the patient's age, no consistent cause-effect relationship has been found between the incidence of tumors and exposure to radiation for diagnostic purposes [27-29]. There is no absolute contraindication to CCTA except iodine contrast allergy or contrast-induced nephrotoxicity. Once the CCTA study has been approved, the aim is to minimize the radiation dose needed to acquire an image of sufficient quality to obtain a correct diagnosis [30]. Despite promising initial results, our study has potential limitations. First, the retrospective design of the study was ideal for post-hoc statistical analysis. However, we based the definition of predicted data on speculations derived from the clinical information contained in the test order because otherwise it would have been more difficult to make predictions. Secondly, cases of CHD in patients attending a medical school hospital are complex and may have been a source of selection bias, possibly leading to overestimation in the results. Lastly, inter-observer variability was not assessed.

\section{Conclusions}

The present study shows that cardiac computed tomography angiography (CCTA) has good diagnostic performance in CHD patients. The use of this technique has an impact on patient progress, prompts a change in patient management in more than a third of patients, and reveals new findings in relation to initial suspicion in $60.4 \%$ of patients. All unexpected reports (100\%) described new findings that prompted changes in management in $86.8 \%$ of patients. Although it would be ideal to conduct more studies of this kind, we consider that the current rapid developments in technology make it difficult to conduct future comparative studies or studies involving other centers.

\section{Acknowledgments}

The authors thank the Faculty of Medicine for its support, and Panaya Tumsatan for her substantial contribution to the present study, including image analysis and manuscript revision.

\section{Disclosure}

Author reports no conflict of interest.

\section{References}

1. Pradat P, Francannet C, Harris JA, Robert E. The epidemiology of cardiovascular defects, part I: a study based on data from three large registries of congenital malformations. Pediatr Cardiol 2003; 24: 195-221.

2. Hoffman JI, Kaplan S. The incidence of congenital heart disease. J Am Coll Cardiol 2002; 39: 1890-1900.

3. Tsai-Goodman B, Geva T, Odegard KC, Sena LM, Powell AJ. Clinical role, accuracy, and technical aspects of cardiovascular magnetic resonance imaging in infants. Am J Cardiol 2004; 94: 69-74.

4. Van der Linde D, Konings EE, Slager MA, Witsenburg M, Helbing WA, Takkenberg JJ, Roos-Hesselink JW. Birth prevalence of congenital heart disease worldwide: a systematic review and meta-analysis. J Am Coll Cardiol 2011; 58: 2241-2247.

5. Goo HW, Park IS, Ko JK, Kim YH, Seo DM, Park JJ. Computed tomography for the diagnosis of congenital heart disease in pediatric and adult patients. Int J Cardiovasc Imaging 2005; 21: 347-365.

6. Hlavacek AM. Imaging of congenital cardiovascular disease: the case for computed tomography. J Thorac Imaging 2010; 25: 247-255.

7. Bergersen L, Everett AD, Giroud JM, Martin GR, Franklin RC, Beland MJ, Krogmann ON, Aiello VD, Colan SD, Elliott MJ, Gaynor JW, Kurosawa H, Maruszewski B, Stellin G, Tchervenkov CI, Walters HL, Weinberg P, Jacobs JP. Report from The International Society for Nomenclature of Paediatric and Congenital Heart Disease: cardiovascular catheterisation for congenital and paediatric cardiac disease (Part 1 - Procedural nomenclature). Cardiol Young 2011; 21: 252-259.

8. Thomas JD, Zoghbi WA, Beller GA, Bonow RO, Budoff MJ, Cerqueira MD, Creager MA, Douglas PS, Fuster V, Garcia MJ, Holmes DR Jr, Manning WJ, Pohost GM, Ryan TJ, Van Decker WA, Wiegers SE; American College of CArdiology Foundation (ACCF); American Heart Association (AHA); American College of Physicians (ACP) Task Force on Clinical Competence and Training. ACCF 2008 Training Statement on Multimodality Noninvasive Cardiovascular Imaging A Report of the American College of Cardiology Foundation/American Heart Association/American College of Physicians Task Force on Clinical Competence and Training Developed in Collaboration With the American Society of Echocardiography, the American Society of Nuclear Cardiology, the Society of Cardiovascular Computed Tomography, the Society for Cardiovascular Magnetic Resonance, and the Society for Vascular Medicine. J Am Coll Cardiol 2009; 53: 125-146.

9. Baumgartner H, Bonhoeffer P, De Groot NM, de Haan F, Deanfield JE, Galie N, Gatzoulis MA, Gohlke-Baerwolf C, Kaemmerer H, Kilner P, Meijboom F, Mul$\operatorname{der}$ BJ, Oechslin E, Oliver JM, Serraf A, Szatmari A, Thaulow E, Vouhe PR, Walma E; Task Force on the Management of Grown-up Congenital Heart Dis- 
ease of the European Society of Cardiology (ESC); Association for European Paediatric Cardiology (AEPC); ESC Committee for Practice Guidelines (CPG). ESC Guidelines for the management of grown-up congenital heart disease (new version 2010). Eur Heart J 2010; 31: 2915-2957.

10. Taylor AJ, Cerqueira M, Hodgson JM, Mark D, Min J, O'Gara P, Rubin GD American College of Cardiology Foundation Appropriate Use Criteria Task Force; Society of Cardiovascular Computed Tomography; American College of Radiology; American Heart Association; American Society of Echocardiography; American Society of Nuclear Cardiology; North American Society for Cardiovascular Imaging; Society for Cardiovascular Angiography and Interventions; Society for Cardiovascular Magnetic Resonance, Kramer CM Berman D, Brown A, Chaudhry FA, Cury RC, Desai MY, Einstein AJ, Gomes AS, Harrington R, Hoffmann U, Khare R, Lesser J, McGann C, Rosenberg A Schwartz R, Shelton M, Smetana GW, Smith SC Jr. ACCF/SCCT/ACR/AHA/ ASE/ASNC/NASCI/SCAI/SCMR 2010 appropriate use criteria for cardiac computed tomography. A report of the American College of Cardiology Foundation Appropriate Use Criteria Task Force, the Society of Cardiovascular Computed Tomography, the American College of Radiology, the American Heart Association, the American Society of Echocardiography, the American Society of Nuclear Cardiology, the North American Society for Cardiovascular Imaging, the Society for Cardiovascular Angiography and Interventions, and the Society for Cardiovascular Magnetic Resonance. J Am Coll Cardiol 2010; 56: 1864-1894.

11. Flohr TG, Stierstorfer K, Ulzheimer S, Bruder H, Primak AN, McCollough CH. Image reconstruction and image quality evaluation for a 64-slice CT scanner with z-flying focal spot Med Phys 2005; 32: 2536-2547.

12. Cademartiri F, Nieman K, van der Lugt A, Raaijmakers RH, Mollet N, Pattynama PMT, de Feyter PJ, Krestin GP. Intravenous contrast material administration at 16-detector row helical CT coronary angiography: test bolus versus bolus-tracking technique. Radiology 2004; 233: 817-823.

13. Van der Bom T, Zomer AC, Zwinderman AH, Meijboom FJ, Bouma BJ, Mulder BJ. The changing epidemiology of congenital heart disease. Nat Rev Cardiol 2011; 8: 50-60.

14. Warnes CA, Liberthson R, Danielson GK, Dore A, Harris L, Hoffman JI, Somerville J, Williams RG, Webb GD. Task force 1: the changing profile of congenital heart disease in adult life. J Am Coll Cardiol 2001; 37: 1170-1175.

15. Lacour-Gayet F, Clarke D, Jacobs J, Comas J, Daebritz S, Daenen W, Gaynor W, Hamilton L, Jacobs M, Maruszsewski B, Pozzi M, Spray T, Stellin G, Tchervenkov C, Mavroudis And C; Aristotle Committee. The Aristotle score: a complexity-adjusted method to evaluate surgical results. Eur J Cardiothorac Surg 2004; 25: 911-924.

16. Lacour-Gayet F, Clarke DR; Aristotle Committee. The Aristotle method: a new concept to evaluate quality of care based on complexity. Curr Opin Pediatr 2005; 17: 412-417.

17. Le Bret E, Macé L, Dervanian P, Folliguet T, Bourriez A, Zoghby J, Lambert V Losay J, Martin-Bouyer Y, Neveux JY. Images in cardiovascular medicine: combined angiography and three-dimensional computed tomography for assessing systemic-to-pulmonary collaterals in pulmonary atresia with ventricular septal defect. Circulation 1998; 98: 2930-2931.

18. Lee T, Tsai I, Fu Y. Using multidetector-row CT in neonates with complex congenital heart disease to replace diagnostic cardiac catheterization for anatomical investigation: initial experiences in technical and clinical feasibility. Pediatr Radiol 2006; 36: 1273-1282.
19. Bean MJ, Pannu H, Fishman EK. Three-dimensional computed tomographic imaging of complex congenital cardiovascular abnormalities. J Comput Assist Tomogr 2005; 29: 721-724.

20. Secchi F, Di Leo G, Papini GD, Nardella VG, Negura D, Carminati M, Sardanelli F. Cardiac magnetic resonance: impact on diagnosis and management of patients with congenital cardiovascular disease. Clin Radiol 2011; 66: 720-725.

21. Eichhorn JG, Fink C, Long F, Arnold R, Ley S, Ulmer H, Kauczor HU. Multide tector CT for the diagnosis of congenital vascular anomalies and associated complications in newborns and infants. Rofo 2005; 177: 1366-1372.

22. Lee T, Tsai IC, Fu YC, Jan SL, Wang CC, Chang Y, Chen MC. Using multidetector-row $\mathrm{CT}$ in neonates with complex congenital heart disease to replace diagnostic cardiac catheterization for anatomical investigation: initial experiences in technical and clinical feasibility. Pediatr Radiol 2006; 36: 1273-1282.

23. Vastel-Amzallag C, Le Bret E, Paul JF, Lambert V, Rohnean A, El Fassy E, SigalCinqualbre A. Diagnostic accuracy of dual-source multislice computed tomographic analysis for the preoperative detection of coronary artery anomalies in 100 patients with tetralogy of Fallot. J Thorac Cardiovasc Surg 2011; 142: 120-126.

24. Hendel RC, Patel MR, Kramer CM, Poon M, Hendel RC, Carr JC, Gerstad NA, Gillam LD, Hodgson JM, Kim RJ, Kramer CM, Lesser JR, Martin ET, Messer JV, Redberg RF, Rubin GD, Rumsfeld JS, Taylor AJ, Weigold WG, Woodard PK, Brindis RG, Hendel RC, Douglas PS, Peterson ED, Wolk MJ, Allen JM, Patel MR; American College of Cardiology Foundation Quality Strategic Directions Committee Appropriateness Criteria Working Group; American College of Radiology; Society of Cardiovascular Computed Tomography; Society for Cardiovascular Magnetic Resonance; American Society of Nuclear Cardiology; North American Society for Cardiac Imaging; Society for Cardiovascular Angiography and Interventions; Society of Interventional Radiology. ACCF/ ACR/SCCT/SCMR/ASNC/NASCI/SCAI/SIR 2006 appropriateness criteria for cardiac computed tomography and cardiac magnetic resonance imaging: a report of the American College of Cardiology Foundation Quality Strategic Directions Committee Appropriateness Criteria Working Group, American College of Radiology, Society of Cardiovascular Computed Tomography, Society for Cardiovascular Magnetic Resonance, American Society of Nuclear Cardiology, North American Society for Cardiac Imaging, Society for Cardio vascular Angiography and Interventions, and Society of Interventional Radiology. J Am Coll Cardiol 2006; 48: 1475-1497.

25. Aviram G, Sharony R, Kramer A, Nesher N, Loberman D, Ben-Gal Y, Graif M, Uretzky G, Mohr R. Modification of surgical planning based on cardiac multidetector computed tomography in reoperative heart surgery. Ann Thorac Surg 2005; 79: 589-595.

26. Kasar PA, Ravikumar R, Varghese R, Kotecha M, Vimala J, Kumar RN. Computed tomographic angiography in tetralogy of Fallot. Asian Cardiovasc Thorac Ann 2011; 19: 324-332.

27. Boxt LM. CT angiography in children: it is accurate, but is it safe? JACC Cardiovasc Imaging 2008; 1: 340-342.

28. Huang B, Law MW, Mak HK, Kwok SP, Khong PL. Pediatric 64-MDCT coronary angiography with ECG-modulated tube current: radiation dose and cancer risk. AJR Am J Roentgenol 2009; 193: 539-544.

29. Mariotti L, Facoetti A, Bertolotti A, Ranza E, Alloni D, Ottolenghi A. Radiation induced perturbation of cell-to-cell signalling and communication. Radiat Prot Dosimetry 2011; 143: 294-300.

30. Justino $\mathrm{H}$. The ALARA concept in pediatric cardiac catheterization: techniques and tactics for managing radiation dose. Pediatr Radiol 2006; 36 Suppl 2: 146-153. 